Olena KOLOMIYETS, orcid.org/0000-0003-4169-7089 University Teacher at the Department of English Language and Its Teaching Methods Pavlo Tychyna Uman State Pedagogical University (Uman, Cherkasy region, Ukraine) o.kolomiyets@udpu.edu.ua

\title{
INTERNATIONALIZATION OF HIGHER EDUCATION PROCESSES OF UKRAINE ON THE EXAMPLE OF PAVLO TYCHYNA UMAN STATE PEDAGOGICAL UNIVERSITY
}

The article is devoted to the analysis of the processes of globalization and internationalization of pedagogical universities of Ukraine. Priority types of international activity of a modern institution of higher education are determined. The main directions and tasks of dissemination of international activity of universities are investigated. Incorporating the international dimension into all aspects of higher education management is an extremely important task for modern higher education. The purpose of internationalization of a modern institution of higher education is to improve the quality of teaching, learning, research. Improving forms of cooperation under signed agreements and introducing new forms of cooperation with foreign partners, scientific and educational institutions contribute to raising and strengthening the positive image of higher education institutions in the international arena, creating and developing curricula with foreign language teaching, developing curricula and courses together with foreign countries. Partner universities also promote the prestige of Ukrainian higher education institutions in the international education market in order to attract foreign students. Joint research and exchange of experience in teaching through the invitation of teachers from leading foreign universities and internships of teachers of Ukrainian universities is a priority to establish strong relations between higher education institutions around the world.

The international activity of Pavlo Tychyna Uman State Pedagogical University (hereinafter - USPU) can serve as an example of an active position in establishing and expanding ties with foreign educational, scientific and cultural institutions during the internationalization of higher education in Ukraine. The international project activity of USPU is investigated, in particular in the question of modernization of curricula of pedagogical establishments of higher education of Ukraine by introduction of the most modern methods of teaching with use of computer technologies and methods of research of results (MoPED). An important indicator of the university's international activity is also participation in a number of projects of the Ukrainian Educational Researchers Association (UERA), as well as internships of USPU professors and researchers on various programs and projects at leading European universities. The importance of the analysis of the policy of international activity of USPU for its implementation in other pedagogical universities is reflected.

Key words: internationalization, international activity, institutions of higher education, Pavlo Tychyna Uman State Pedagogical University.

олена КОЛОМІЕЦЬ, orcid.org/0000-0003-4169-7089 викладач кафедри англійської мови та методики ї̈ навчання Уманського державного педагогічного університету імені Павла Тичини (Умань, Черкаська область, Україна) o.kolomiyets@udpu.edu.иа

\section{ІНТЕРНАЦІОНАЛІЗАЦІЯ ПРОЦЕСІВ ВИЩОЇ ОСВІТИ УКРАЇНИ НА ПРИКЛАДІ УМАНСЬКОГО ДЕРЖАВНОГО ПЕДАГОГІЧНОГО УНІВЕРСИТЕТУ ІМЕНІ ПАВЛА ТИЧИНИ}

\footnotetext{
Статтю присвячено аналізу процесів глобалізації та інтернаціоналізації педагогічних університетів України. Визначені пріоритетні види міжнародної діяльності сучасного закладу вищої освіти. Досліджені основні напрями й завдання з поширення міжнародної діяльності університетів. Включення інтернаціонального виміру в усі аспекти управління закладом вищзої освіти є надзвичайно важливим завданням сучасної вищої школи. Метою інтернаціоналізації сучасного закладу вищої освіти є підвищення якості викладання, навчання, науково-дослідницької діяльності. Удосконалення форм співпраці згідно з підписаними договорами й впровадження нових форм співробітництва із закордонними партнерами, науковими й освітніми закладами сприяють підвищенню та укріпленню позитивного іміджу закладу вищої освіти на міжнародній арені; створення та розвиток навчальних програм із викладанням іноземною мовою, розробка навчальних програм і курсів спільно із закордонними університетами-партнерами також сприяють підвищенню престижу украӥнських закладів вищої освіти на міжнародному освітньому ринку з метою залучення іноземних студентів. Спільна науково-дослідна робота й обмін досвідом із викладащької діяльності завдяки запрошенню викладачів провідних зарубіжних університетів
} 
і стажуванню викладачів украӥнських університетів є пріоритетним напрямом встановлення міцних стосунків між закладами вищої освіти в усьому світі. Міжнародна діяльність Уманського державного педагогічного університету імені Павла Тичини може слугувати прикладом активної позиції у встановленні й розщиренні зв'язків із закордонними закладами освіти, науки й культури в період інтернаціоналізації вищої освіти Украӥни. Досліджено міжнародну проєктну діяльність Уманського державного педагогічного університету, зокрема в питанні модернізачії навчальних планів педагогічних закладів вищої освіти України шляхом впровадження найсучасніших методів викладання з використанням комп'ютерних технологій і методів дослідження результатів (МоРЕD). Важливим показником міжнародної діяльності університету є також співучасть у ряді проєктів Української асоиіації дослідників освіти (УАДО), а також стажування професорсько-викладацького складу Уманського державного педагогічного університету за різноманітними програмами й проєктами в провідних університетах Свропи. Відбито важливість аналізу політики міжнародної діяльності Уманського державного педагогічного університету для ї̈ імплементації в інші педагогічні університети.

Ключові слова: інтернаціоналізація, міжнародна діяльність, заклади вищої освіти, Уманський державний педагогічний університет імені Павла Тичини.

Statement of the problem. One of the main tasks of a modern higher education institution (hereinafter-HEI) is active integration into the world educational space, which is solved by including the international dimension in all aspects of HEI in order to improve the quality of education, research and formation of necessary competencies in students. Issues of teaching foreign students, the development of academic mobility, the participation of universities in international projects are extremely relevant today and require an analytical approach to research.

The problem of international activity of modern pedagogical universities requires the use of methodological approaches that allow to ensure the systematic organization of the process of international activity on the basis of active interaction of all its participants with a focus on achieving a guaranteed result.

Analysis of recent research and publications. The following aspects of Ukrainian and foreign scientists are devoted to the educational aspects of international cooperation of HEIs: V. Andrushchenko, T. Antonyuk, Ya. Bolyubash, M. Debych, S. Shitikova, V. Zhuravsky, I. Sikorska, A. Verbytska, V. Kremen, F. Altbach, H. Wit, J. Knight, L. Rumbley and many other authors.

The purpose of the article. Despite the large number of original and meaningful works of Ukrainian and foreign scientists on the internationalization of higher education, it should be noted that the problem of research and analysis of international cooperation experience of Pavlo Tychyna Uman State Pedagogical University (hereinafter - USPU) is insufficiently studied.

The purpose of the work is to study and analyze the active international activities of the USPU for further application of this experience by other pedagogical universities of Ukraine.

Presenting main material. The development of globalization and internationalization of the world economy requires higher education to train professionals capable of working effectively in a changing global economic system (Korolova, 2013: 1). Globalization of professional knowledge and internationalization of higher education processes are designed to strengthen the international activities of HEIs (Sikorska, 2015: 268). Priority types of international activity of a modern HEI include: international cooperation in education and science; organization of foreign mobility of students and teachers; improving existing and creating new international student exchange programs; implementation of double degree programs; recruitment of foreign students; international projects (Stepanenko, Debych, 2017: 28).

The international activity of a HEI affects its image, promotes its development, is a driving force for improving the educational and scientific processes of a university.

In general, we can identify the following main areas and objectives for the dissemination of international activities of a HEI:

- raising and strengthening the positive image of the HEI in the international educational arena (inclusion of the international dimension in all aspects of HEI's management in order to improve the quality of teaching, learning, research; effective reform of HEI in accordance with the main provisions of the Bologna Declaration);

- introduction of new forms of cooperation with foreign partners, scientific and educational institutions for mutually beneficial cooperation (improvement of forms of cooperation according to signed agreements; creation of stable international relations in educational and scientific activities; active use of new principles and organizational forms of partnership);

- increasing the prestige of the HEI in the international educational market in order to attract foreign students (creation and development of curricula with foreign language teaching at the educational qualification level - Bachelor and Master; development of curricula and courses together with foreign partner universities for joint recognition of degrees); 
Kolomiyets O. Internationalization of higher education processes of Ukraine on the example...

- improving the quality of education and research with the experience of leading European universities (active use of international cooperation with foreign HEIs for joint research and exchange of teaching experience; expanding the participation of HEIs in joint educational and research projects funded by internationals programs);

- organization and coordination of mobility for students and teachers under agreements or international projects and programs (development of student and teacher mobility through wider coverage, information and promotion of international educational programs to get acquainted with other cultures, study international experience, and also increasing the level of foreign language proficiency);

- achieving recognition of the HEI in the European Higher Education Area (membership in international educational organizations, associations, etc; participation in international conferences (presentations, reports, publications in conference proceedings) abroad; organization and holding of international conferences as a host institution with foreign experts);

- creating conditions to ensure an integral and systematic approach to the internationalization of educational and scientific activities (Omelianchuk, Sikorska, 2007: 48).

The practical implementation of the new paradigm of higher education in Ukraine requires in-depth research of international activities, i.e. the study of the history and experience of Western higher education in creating a foundation for mobility of all participants in the educational process in a globalized educational space. It is worth mentioning that academic mobility in the field of international cooperation in higher education cannot be reduced to specific actions, technologies or mechanisms related to the exchange system of scientists, teachers and students of the HEIs of different countries. This is a complex process of intellectual movement, exchange of scientific and cultural potential, resources, learning technologies. International academic mobility is also seen as a necessary condition for the effective development of education and science, an integral and important part of university activities. Mobility of students and teachers is one of the basic principles of modern higher education. Studying, internships and research abroad enrich the individual experience, provide an opportunity to learn about different models of knowledge creation and dissemination, expand the network of contacts and communication, deepen knowledge of foreign languages (Higher Education in Ukraine and the Bologna Process, 2004: 67).
During the study period, Pavlo Tychyna Uman State Pedagogical University (USPU) took an active position in establishing and expanding ties with foreign educational, scientific and cultural institutions, guided by such regulations as "Strategy for Ukraine's integration into the European Union", the Law "On higher education", the Regulation on the procedure for exercising the right to academic mobility (2015), the program of international research and innovation "Horizon 2020". Based on these regulations and programs, Regulations on academic mobility of teachers and research and teaching staff and Regulations on the implementation of the right to academic mobility by higher education of USPU (2016) were developed. They are based on international educational and scientific cooperation of the University. In September 2015, the Department of Research, Innovation and International Cooperation was established, the positions of Vice-Rector for Research and International Cooperation and Coordinator for International Affairs of the University were introduced. There are three cultural and educational centers on the basis of the USPU: the Polish Cultural and Educational Center (since 2007), the Ukrainian-Israeli Center for Education, Science and Culture (since 2012) and the Ukrainian-Turkmen Cultural and Educational Center (since 2016) (Report of the Rector of Pavlo Tychyna Uman State Pedagogical University, 2016: 88).

During the study period, international cooperation of the USPU was carried out comprehensively and systematically at the level of the Rectorate, the Department of Scientific and Technical Development and European Integration, cultural and educational centers, departments and faculties. Work was carried out within the framework of academic mobility projects (Mobile +2 , Mobile +3 , Erasmus +, Melvana, Stipendium Hungaricum), as well as dual diploma programs aimed at supporting initiatives in the fields of education and culture.

In particular, in April 2016, a delegation of the Institute of European Culture of the Adam Mickiewicz University of Poznan in Gniezno (Poland) visited USPU. During the meeting, the prospects of further cooperation in the implementation of the double degree program, which has been running since 2009 , were discussed. This program is very important for USPU, as it is to enable university students to obtain a European diploma. (Report of the Rector of Pavlo Tychyna Uman State Pedagogical University, 2016: 89).

In the framework of the project "Promoting the development of regional English-speaking professional communities in Ukraine", which was introduced by a public organization "Ukrainian Branch of the International Association of Teachers 
of English as a Foreign Language" (IATEFL Ukraine) with the support of the British Council in Ukraine in 2020, a Regional English-language educational hub was established. English Learning Hub is a new association for professional development and exchange of experience among research and teaching staff, students and anyone who studies or teaches English (Report of the Rector of Pavlo Tychyna Uman State Pedagogical University, 2020: 59).

The University also actively worked within the consortium of the project "Modernization of pedagogical higher education using innovative teaching tools" (MoPED) of the program "Development of higher education potential", Erasmus +, KA-2. The main goal of the project is to modernize the curricula of pedagogical HEIs of Ukraine by introducing the most modern teaching methods using computer technology and research methods. The MoPED project has a great impact on the quality of Ukrainian higher pedagogical education and serves as a basis for improving the digital and didactic competencies of future school teachers, which fully meets the problems and requirements of pedagogical higher education and supports largescale educational reforms in Ukraine.

Within the framework of the MoPED international grant project, the Center for Advanced Educational Technologies "USPU Ecosystem" operates at USPU natural-mathematical and computer-oriented disciplines (Report of the Rector of Pavlo Tychyna Uman State Pedagogical University, 2020: 60).

It is also worth noting the implementation of international projects "Active Citizens" (British Council program for youth in the field of intercultural dialogue and social development (2019/2020), "Student Action" (student leadership development program), the project "Academic integrity as a component of quality Educational Process", which received assistance from the British Council in 2020, the EU project Erasmus+ "European indicators of the quality of educational research to empower educators in Ukraine" (Report of the Rector of Pavlo Tychyna Uman State Pedagogical University, 2020: 58).

An important indicator of active international activity of the University is also participation in a number of projects of the Ukrainian Educational Researchers Association (UERA): "European Quality Indicators of Educational Research to Empower Educators in Ukraine" (Jean Monnet Support to Associations Project), funded by the European Commission (2016-2020); "School Activity" (Learning through Play) (Lego Foundation, Australian Board of Education Researchers) (2020-2021); "When Science is a Woman" (in partnership with
Adam Mickiewicz University of Poznan, grant from Université Paris Dauphine); as well as the Jean Monnet project of the National Academy of Pedagogical Sciences of Ukraine "European Quality of Education for Better Student Achievement" and the joint project with Andriy Makarenko Sumy State Pedagogical University "Europeanization of Doctoral Programs in Education Based on Interdisciplinary and Inclusive Approaches" Erasmus + Jean Monnet (K3) (Report of the Rector of Pavlo Tychyna Uman State Pedagogical University, 2020: 60).

Since March 2020, the USPU Cisco Academy has been operating on the basis of the Faculty of Physics, Mathematics and Informatics of the University. Cisco Academy is an international educational program in the field of IT and cybersecurity, which brings together partner freelancers around the world (Report of the Rector of Pavlo Tychyna Uman State Pedagogical University, 2020: 60).

Internships of USPU faculty members on various programs and projects at the University of Porto (Porto, Portugal) were also quite active during the study period; Comenius State Higher School of Vocational Education (Leszno), Jan Dlugosz University of Natural Sciences and Humanities (Czestochowa), Foundation ADD (Warsaw), Pedagogical University named after Public Education Commission (Krakow), John Paul II Catholic University of Lublin (Lublin), Humanities and Pedagogy University (Sandomierz), at the Higher School of Linguistics (Czestochowa), at the Eastern European Center for Basic Research (Prague, Czech Republic), at the University of Suceava named after Stefan cel Mare (Suceava, Romania), at the Hebrew Language Academy (Jerusalem, Israel), under the Leadership Development Program of Ukrainian Universities at the University of Edinburgh (Murray School of Education, UK), under the MoPED project "Capacity Development of Higher Education", Erasmus+, KA-2 at the University of Deusto (Spain) (Reports of the Rector of Pavlo Tychyna Uman State Pedagogical University, 2016, 2017, 2018, 2019, 2020).

Each year, more than 60 students participated in academic mobility programs, as well as regular meetings with participants in academic mobility and presentations of new learning opportunities abroad.

The interest of foreign partners in the activities of the Pavlo Tychyna State Pedagogical University testifies to effective work aimed at ensuring quality student training, expanding educational, scientific and cultural ties and positioning the university in partner countries as a promising and developing HEI.

Conclusions. Based on the study, it can be concluded that the international activity of USPU is characterized by active deepening of the university 
Kolomiyets O. Internationalization of higher education processes of Ukraine on the example...

in the world educational and scientific space, by good indicators of international academic mobility, project activities, attracting foreign funding through grant programs Erasmus +, Jean Monnet and others, as well as by implementation of innovative methods of organizing the educational process and research at the University.

The obtained research results can be used to improve the international activities of pedagogical universities of Ukraine.

\section{BIBLIOGRAPHY}

1. Вища освіта України і Болонський процес : навчальний посібник / Авторський колектив : М.Ф. Степко, Я.Я. Болюбаш, В.Д. Шинкарук, В.В. Грубінко, І.І. Бабин. Тернопіль : Навчальна книга. Богдан, 2004. 384 с.

2. Звіт ректора Уманського державного педагогічного університету імені Павла Тичини про виконання умов контракту з Міністерством освіти і науки України за 2016 рік. Умань, 2016. 198 c. URL: https://udpu.edu.ua/documents/doc.2016BA.pdf.

3. Звіт ректора Уманського державного педагогічного університету імені Павла Тичини про виконання умов контракту з Міністерством освіти і науки України за 2017 рік. Умань, 2017. 129 с. URL: https://udpu.edu.ua/documents/doc.2017BA.pdf.

4. Звіт ректора Уманського державного педагогічного університету імені Павла Тичини про виконання умов контракту з Міністерством освіти і науки України за 2018 рік. Умань, 2018. 107 с. URL: https://udpu.edu.ua/documents/ doc.2018BA.pdf.

5. Звіт ректора Уманського державного педагогічного університету імені Павла Тичини про виконання умов контракту з Міністерством освіти і науки України за 2019 рік. Умань, 2019. 111 с. URL: https:/udpu.edu.ua/documents/ doc.2019BA.pdf.

6. Звіт ректора Уманського державного педагогічного університету імені Павла Тичини про виконання умов контракту з Міністерством освіти і науки України за 2020 рік. Умань, 2020. 111 с. URL: https:/udpu.edu.ua/documents/ doc.2020BA.pdf.

7. Корольова Т.С. Інтеграція вищої освіти України до європейського освітянського простору в умовах глобалізації. Національна економіка у сучасній глобальній економічній системі: механізми функціонування, динаміка, економічна безпека : матеріали конференції. Полтава, 2010. С. 28-32.

8. Омельянчук А.І., Сікорська І.М. Міжнародне співробітництво як фактор реалізації політики держави в галузі вищої освіти. Розвиток міжнародного співробітництва в галузі освіти в контексті Болонського процесу. Ялта : Кримський гуманітарний університет, 2007. С. 45-51.

9. Сікорська I.M. Аналіз міжнародної діяльності вищого навчального закладу як стратегічного напряму інтернаціоналізації. Вищза освіта Украӥни. 2015. № 3. С. 268-277.

10. Степаненко I.В., Дебич М.А. Інтернаціоналізація як інструмент розвитку лідерського потенціалу університету : навчальний посібник. Київ : ДП «НВЦ «Пріоритети», 2017. 44 с.

11. Хан С.В. Інтеграція України у європейський простір вищої освіти як складова цивілізаційного вибору. Вісник Київського національного університету імені Тараса Шевченка. Історія. 2015. Вип. 3. С. 54-57.

\section{REFERENCES}

1. Vyshcha osvita Ukrainy i Bolonskyi protses: navch. posibnyk [Higher Education in Ukraine and the Bologna Process] (2004). Avtorskyi kolektyv: Stepko M.F., Boliubash Ya.Ya., Shynkaruk V.D., Hrubinko V.V., Babyn I.I. Ternopil: Navchalna knyha. Bohdan, 2004. 384 p. [in Ukrainian].

2. Zvit rektora Umanskoho derzhavnoho pedahohichnoho universytetu imeni Pavla Tychyny pro vykonannia umov kontraktu z Ministerstvom osvity i nauky Ukrainy za 2016 rik [Report of the Rector of Pavlo Tychyna Uman State Pedagogical University on the Fulfillment of the Terms of the Contract with the Ministry of Education and Science of Ukraine for 2016]. Uman, 2016. 198 p. [in Ukrainian]. URL: https://udpu.edu.ua/documents/doc.2016BA.pdf.

3. Zvit rektora Umanskoho derzhavnoho pedahohichnoho universytetu imeni Pavla Tychyny pro vykonannia umov kontraktu z Ministerstvom osvity i nauky Ukrainy za 2017 rik [Report of the Rector of Pavlo Tychyna Uman State Pedagogical University on the Fulfillment of the Terms of the Contract with the Ministry of Education and Science of Ukraine for 2017]. Uman, 2017. 129 p. [in Ukrainian]. URL: https://udpu.edu.ua/documents/doc.2017BA.pdf.

4. Zvit rektora Umanskoho derzhavnoho pedahohichnoho universytetu imeni Pavla Tychyny pro vykonannia umov kontraktu z Ministerstvom osvity i nauky Ukrainy za 2018 rik [Report of the Rector of Pavlo Tychyna Uman State Pedagogical University on the Fulfillment of the Terms of the Contract with the Ministry of Education and Science of Ukraine for 2018]. Uman, 2018. 107 p. [in Ukrainian]. URL: https://udpu.edu.ua/documents/doc.2018BA.pdf.

5. Zvit rektora Umanskoho derzhavnoho pedahohichnoho universytetu imeni Pavla Tychyny pro vykonannia umov kontraktu z Ministerstvom osvity i nauky Ukrainy za 2019 rik [Report of the Rector of Pavlo Tychyna Uman State Pedagogical University on the Fulfillment of the Terms of the Contract with the Ministry of Education and Science of Ukraine for 2019]. Uman, 2019. 111 p. [in Ukrainian]. URL: https://udpu.edu.ua/documents/doc.2019BA.pdf.

6. Zvit rektora Umanskoho derzhavnoho pedahohichnoho universytetu imeni Pavla Tychyny pro vykonannia umov kontraktu z Ministerstvom osvity i nauky Ukrainy za 2020 rik [Report of the Rector of Pavlo Tychyna Uman State Pedagogical University on the Fulfillment of the Terms of the Contract with the Ministry of Education and Science of Ukraine for 2020]. Uman, 2020. 111 p. [in Ukrainian]. URL: https://udpu.edu.ua/documents/doc.2020BA.pdf.

7. Korolova T.S. (2013). Intehratsiia vyshchoi osvity Ukrainy do yevropeiskoho osvitianskoho prostoru v umovakh hlobalizatsii [Integration of higher education in Ukraine into the European educational space in the context of globalization]. Odeskyi derzhavnyi ekonomichnyi universytet, m. Odesa, 2013. pp. 1-4. [in Ukrainian]. 
8. Omelianchuk A.I., Sikorska I.M. (2007). Mizhnarodne spivrobitnytstvo yak faktor realizatsii polityky derzhavy v haluzi vyshchoi osvity [International cooperation as a factor in the implementation of state policy in the field of higher education]. Rozvytok mizhnarodnoho spivrobitnytstva v haluzi osvity v konteksti Bolonskoho protsesu. Yalta: Krymskyi humanitarnyi universytet, 2007. pp. 45-51. [in Ukrainian].

9. Sikorska I.M. (2015). Analiz mizhnarodnoi diialnosti vyshchoho navchalnoho zakladu yak stratehichnoho napriamu internatsionalizatsii [Analysis of the international activity of a higher education institution as a strategic direction of internationalization]. Vyshcha osvita Ukrainy, 2015. № 3. pp. 268-277. [in Ukrainian].

10. Stepanenko I., Debych M. (2017). Internatsionalizatsiia yak instrument rozvytku liderskoho potentsialu universytetu [Internationalization as a tool for developing the leadership potential of the university]: navchalnyi posibnyk. K. : DP "NVTs "Priorytety", 2017. 44 p. [in Ukrainian].

11. Khan Ye. (2015). Intehratsiia Ukrainy u yevropeiskyi prostir vyshchoi osvity yak skladova tsyvilizatsiinoho vyboru [Ukraine's integration into the European space of higher education as a component of civilization's choice]. Visnyk Kyivskoho natsionalnoho universytetu imeni Tarasa Shevchenka, 2015. Istoriia. № 3. pp. 54-57. [in Ukrainian]. 